\title{
水銀アドアトム修飾金電極上での 過酸化水素の還元反応における電気化学振動現象
}

\author{
上杉 慎治 ${ }^{\mathrm{a}}$, 勝間田哲朗 $\mathrm{a}$, 松本 太 ${ }^{\mathrm{a}, *}$, 小浦 延幸 ${ }^{\mathrm{a}}$, 大坂 武男 ${ }^{\mathrm{b}}$ \\ a 東京理科大学理工学部（テ278-8510 野田市山崎 2641） \\ $\mathrm{b}$ 東京工業大学大学院総合理工学研究科（₹226-8502 橫浜市緑区長津田町 4259)
}

\section{Electrochemical Oscillatory Phenomena during Reduction of Hydrogen Peroxide on Mercury Adatom-modified Au Electrode}

\author{
Shinji UESUGI, ${ }^{\text {a }}$ Tetsurou KATSUMATA, ${ }^{\text {a Futoshi MATSUMOTO, }{ }^{\text {, }} \text { * }}$ \\ Nobuyuki KOURA, and Takeo OHSAKA ${ }^{\mathrm{b}}$
}

\begin{abstract}
${ }^{a}$ Faculty of Science and Technology, Tokyo University of Science (2641 Yamazaki, Noda-shi, Chiba 278-8510, Japan) ${ }^{b}$ Department of Electronic Chemistry, Interdisciplinary Graduate School of Science and Engineering, Tokyo Institute of Technology (4259 Nagatsuta, Midori-ku, Yokohama 226-8502, Japan)
\end{abstract}

Received February 22, 2001 ; Accepted May 28, 2001

\begin{abstract}
Acceleration of the reduction of hydrogen peroxide $\left(\mathrm{H}_{2} \mathrm{O}_{2}\right)$ and electrochemical oscillatory phenomena during the reduction of $\mathrm{H}_{2} \mathrm{O}_{2}$ on $\mathrm{Hg}$ adatom-modified Au polycrystalline electrodes in acidic, neutral and alkaline aqueous solutions were first observed. The observed acceleration of the reduction of $\mathrm{H}_{2} \mathrm{O}_{2}$ was explained by taking into account the electrode potential-dependent electrocatalytic behavior of the adsorbed species of $\mathrm{OH}^{-}\left(\mathrm{OH}_{a d}\right)$ on the $\mathrm{Hg}$ adatom-modified $\mathrm{Au}$ electrode surface. The negative differential resistance (NDR) was observed in the potential region from 0.4 to 0.8 $\mathrm{V}$ vs. $\mathrm{Ag} / \mathrm{AgCl}$, which is indeed characteristic of electrochemical oscillatory phenomena. Moreover, the oscillatory behavior was found to depend on the electrode rotation rate, the direction of potential scan, $\mathrm{pH}$ of the solution and the concentration of $\mathrm{H}_{2} \mathrm{O}_{2}$, similar to that previously observed on $\mathrm{Au}$ [100] and $\mathrm{Ag}$ polycrystalline electrode surfaces during the reduction of $\mathrm{H}_{2} \mathrm{O}_{2}$. A probable explanation for the observed current oscillation is given based on the comparision with the current oscillation behavior on $\mathrm{Au}$ [100] and $\mathrm{Ag}$ polycrystalline electrodes. The reduction of $\mathrm{H}_{2} \mathrm{O}_{2}$ catalyzed by $\mathrm{OH}_{\mathrm{ad}}\left(\mathrm{H}_{2} \mathrm{O}_{2}+\mathrm{H}^{+}+\mathrm{OH}_{\mathrm{ad}}+\mathrm{e}^{-} \longrightarrow 2 \mathrm{OH}_{\mathrm{ad}}+\mathrm{H}_{2} \mathrm{O}\right)$ is an autocatalytic reaction which is characteristic of electrochemical oscillatory phenomena and is controlled by the formation and disappearance of $\mathrm{OH}_{\mathrm{ad}}$ on the $\mathrm{Hg}$ adatommodified Au electrode surface.
\end{abstract}

Key Words : Hydrogen Peroxide, Electrochemical Oscillatory Phenomena, Mercury Adatom-modified Electrode, Negative Differential Resistance

\section{1 緒 言}

水溶液中における白金, 金, 銀および様々な合金電極上で の過酸化水素 $\left(\mathrm{H}_{2} \mathrm{O}_{2}\right)$ の還元反応は, 燃料電池の開発にと って非常に與味深い反応であり，反応機構の解明に関し数多 くの研究が行われている1-10).この還元反応においては, その反応が進行している最中に, 電流あるいは電極電位の振 動現象が観察されることが報告されており，その振動は，用 いる電極基材, $\mathrm{H}_{2} \mathrm{O}_{2}$ の濃度, 電解液の $\mathrm{pH}$ などよって 様々なパターンを示すことが知られている11-16). この振動 現象のメカニズムを明らかにすることは, $\mathrm{H}_{2} \mathrm{O}_{2}$ の還元反応 のメカニズムの解明および還元反応効率の向上に関し新たな 知見を与えると期待される.

本研究では，従来，金電極を用いた場合においては， $\mathrm{Au}$ [100]においてのみ観察されていた $\mathrm{H}_{2} \mathrm{O}_{2}$ の還元反応の促進，

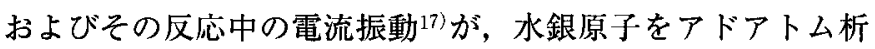

出させることにより多結晶金電極を用いた場合においても観 察されるようになることを初めて見出した. また, $\mathrm{H}_{2} \mathrm{O}_{2}$ の 濃度, $\mathrm{pH}$, 電極回転速度, 電位掃引方向などを変化させる ことにより，振動現象がどのように変化するかという水銀ア ドアトム金電極における基本的な電流振動挙動を検討した. さらにこれまでにまとめられている電気化学振動現象の発 現の概念 ${ }^{18,19)}, A \mathbf{u}(100)$ 面における過酸化水素の還元反応 機構 ${ }^{17)}$, 本研究における実験結果を総合することにより, 水 銀アドアトム修飾金電極上の $\mathrm{H}_{2} \mathrm{O}_{2}$ の還元反応における電流 振動反応のメカニズムについて考察を行った.

\section{2 実 験}

水銀アドアトム修飾金電極の作製に用いた酸化水銀（> 98.0\%）は，和光純薬から購入したものをそのまま用いた。 その他の試薬は特級相当のものを，精製せずに用いた，電気 
化学測定は，作用電極に回転金電極（(有)日厚計測製， $\phi=$ $6 \mathrm{~mm}$ ), 対極に白金線, 参照極に銀/塩化銀電極（塩化カリ ウム飽和)，ポテンショスタットに(有) 日厚計測製 NPGS

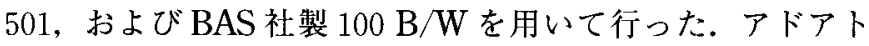
ム電極の作製は，粒径 $1 \mu \mathrm{m}$ のダイヤモンドペーストを用い て十分に電極表面を研磨した後，アセトンおよで水を用いて 洗浄し, 窒素雲囲気 $1 \mathrm{mM} \mathrm{Hg}^{2+}+0.1 \mathrm{M} \mathrm{H}_{2} \mathrm{SO}_{4}$ 溶液中で, 電極電位を 0.75〜1.05 V (vs. $\mathrm{Ag} / \mathrm{AgCl}$ ) の範国でカソード 方向入電位掃引 $\left(10 \mathrm{mVs}^{-1}\right)$ し, 水銀のアンダーポテンシ ヤル析出反応を起こさせることにより行った ${ }^{20)}$. 金電極の実

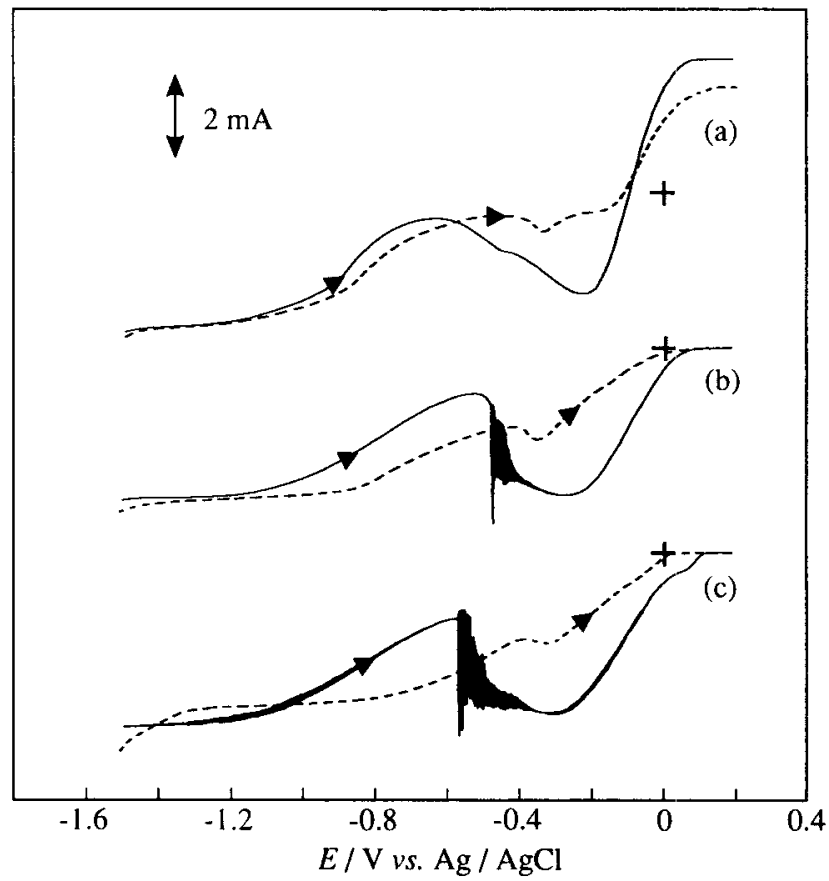

Fig. 1 Typical steady-state voltammograms for the reduction of $\mathrm{H}_{2} \mathrm{O}_{2}$ on $\mathrm{Hg}$ adatom-modified (solid line) and bare (dotted line) rotating disk $\mathrm{Au}$ electrodes in deaerated solutions of $\mathrm{pH}$ 13.0 (a), 9.5 (b) and 3.0 (c) containing $0.1 \mathrm{M} \mathrm{KCl}$ and 10.0 $\mathrm{mM} \mathrm{H}_{2} \mathrm{O}_{2}$. Electrode rotation rate: $400 \mathrm{rpm}$, potential scan rate: $3 \mathrm{mVs}^{-1}$.

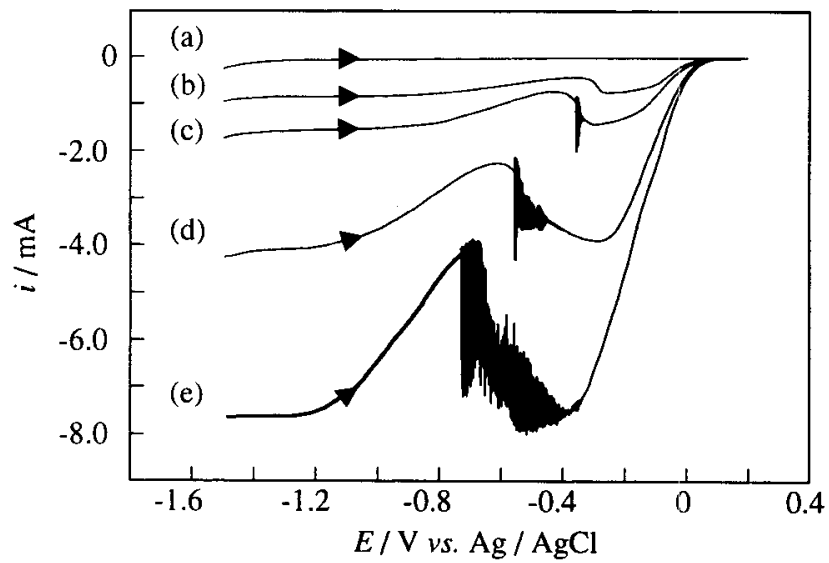

Fig. 2 Typical steady-state voltammograms for the reduction of $\mathrm{H}_{2} \mathrm{O}_{2}$ on $\mathrm{Hg}$ adatom-modified rotating disk $\mathrm{Au}$ electrode in deaerated solutions of $\mathrm{pH} 7$ containing $0.1 \mathrm{M} \mathrm{KCl}$ and (a) 0.0 , (b) 2.1 , (c) 4.2 , (d) 10.0 and (e) $20.0 \mathrm{mM} \mathrm{H}_{2} \mathrm{O}_{2}$. Electrode rotation rate: $400 \mathrm{rpm}$, potential scan rate: $3 \mathrm{mVs}^{-1}$.
表面積は，金電極表面の酸化物層の生成および還元に基づく 電気量から電気化学的に評価し21)，その值は $0.283 \mathrm{~cm}^{2}$ であ った。また，水銀原子の表面被覆率は，アンダーポテンシャ ル析出反応 $\left(\mathrm{Hg}^{2+}+2 \mathrm{e}^{-} \longrightarrow \mathrm{Hg}\right)^{20)}$ における電気量に基づ き，0.29 と見積もられた. $\mathrm{pH} 3.0 ， 7.0 ， 9.5$ および 13.0 の溶 液は, $\mathrm{H}_{2} \mathrm{SO}_{4}, \mathrm{NaOH}$ および超純水（>18 M 2 ) を用いて 調製され，すべての溶液に $0.1 \mathrm{M} \mathrm{KCl}$ を含有させた。また，

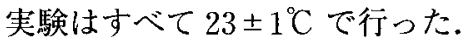

\section{3 結果と考察}

Fig. 1 は，窒素雾团気下における様々な水素イオン濃度の 水溶液中で, 金および水銀アドアトム修飾金回転円盤電極で 得られた $\mathrm{H}_{2} \mathrm{O}_{2}(10.0 \mathrm{mM})$ の還元反応に対する対流ボル夕 モグラムを示している. $\mathrm{pH} 13.0$ の溶液中における $\mathrm{H}_{2} \mathrm{O}_{2}$ の 還元反応を見てみると，未修飾の金電極では $\mathrm{H}_{2} \mathrm{O}_{2}$ の還元反 応は, 約 $-0.8 \mathrm{~V}$ (vs. $\mathrm{Ag} / \mathrm{AgCl}$ ) より負の電位で起こる が19)，水銀アドアトム修飾電極においては， $-0.2 \sim-0.6 \mathrm{~V}$ の範囲に扔いて還元電流が観察されることから，水銀アドア 卜ム修飾電極においては， $\mathrm{H}_{2} \mathrm{O}_{2}$ の還元反応が促進されてい ることがわかる. $\mathrm{pH} 9.5$ 以下の溶液においても同様の挙動 が見られる.また，未修飾金電極でのー0.8〜0Vに見られる 還元電流は, 電極表面における $\mathrm{H}_{2} \mathrm{O}_{2}$ の不均化反応で生成し た酸素分子の還元反心によるものであり，- $-0.35 \mathrm{~V}$ 付近に見 られる小さな還元ピーク電流は，多結晶金電極表面において 露出している [100] 面における $\mathrm{H}_{2} \mathrm{O}_{2}$ の還元反応によるも のと考えられる20).さらに, $\mathrm{pH} 13.0$ の溶液において $0 \sim 0.2$ $\mathrm{V}$ 付近に $\mathrm{H}_{2} \mathrm{O}_{2}$ の酸化電流が見られる.この電流は, 水銀乃 ドアトム修飾電極においてより大きな值を示し, 明確な電極 回転速度依存性を示していることから，水銀アドアトム修飾 電極においては, $\mathrm{H}_{2} \mathrm{O}_{2}$ の還元反応と同様に $\mathrm{H}_{2} \mathrm{O}_{2}$ の酸化反 応も促進されていることがわかる。一方, 電流振動に関して は，Fig.1-(b) と（c）から明らかなように, pH 9.5以下の 溶液において, $-0.5 \mathrm{~V}$ 付近の $\mathrm{H}_{2} \mathrm{O}_{2}$ の還元電流が減少し始 める電位から電流の振動が観察され, その振幅と振動が観察 される電位幅は $\mathrm{pH}$ が低くなるにつれて大きくなることがわ かった。 また, Fig. 2 に示すように $\mathrm{H}_{2} \mathrm{O}_{2}$ の濃度が高くなる につれて，振幅および振動が観察される電位幅が大きくなる 傾向が観察された。 また，振動現象の観察後, 硫酸溶液中に おいて水銀アドアトム電極のアドアトム原子を電解溶出させ た場合，アドアトム析出させた場合と同様の電位において水 銀の溶解電流及び電気量が観察されたことから, 金電極表面 に存在する水銀原子を消費することにより， $\mathrm{H}_{2} \mathrm{O}_{2}$ の還元反 応の促進及び振動現象が生じているのではないことが確認さ れた。

このようなー0.6〜ー0.2 Vの範囲における $\mathrm{H}_{2} \mathrm{O}_{2}$ の還元電 流および-0.5 V 付近からの電流振動現象は, 金 [100] 単結 晶電極 ${ }^{17}$ ， および銀多結晶電極 ${ }^{13)}$ などおいても報告され, それらの機構が詳しく考察されている。これらの電極におい ては, $\mathrm{H}_{2} \mathrm{O}_{2}$ の還元反応が起こる電位付近において電極表面 に吸着している $\mathrm{OH}$ 種 $\left(\mathrm{OH}_{\mathrm{ad}}\right)$ が $\mathrm{H}_{2} \mathrm{O}_{2}$ の還元反応を促進 (式(2)）すると考えられている ${ }^{13,17)}$. 水銀アドアトム電極に おいても，ほとんど同様な電位で $\mathrm{H}_{2} \mathrm{O}_{2}$ の還元反応の促進が 観察されていることから，この $\mathrm{OH}_{\mathrm{ad}}$ が, 式(1) の反応に従 い水銀アドアトム電極表面に生成し，アドアトム電極表面に 安定に存在することにより式(2) の触媒として働き, $\mathrm{H}_{2} \mathrm{O}_{2}$ 
の還元反応を促進していると考えることができる。つまり， 水銀アドアトム電極においては，一0.5〜 - $0.2 \mathrm{~V} の$ 範囲にお いて $\mathrm{OH}_{\mathrm{ad}}$ が安定に存在できる状況を水銀原子をアドアトム 析出させることにより作り出していると推測される。また, 振動現象に関しては，一般に，この現象の発現のためには負 性抵抗 (NDR, negative differential resistance) が必要で あると言わ扎ており，白金電極に抢ける $\mathrm{H}_{2} \mathrm{O}_{2}$ の還元反応に おいては，このNDRの生じる原因を水素イオンの還元反応 で生成した水素原子による $\mathrm{H}_{2} \mathrm{O}_{2}$ の還元反応のための電極表 面吸着サイトの占有によると考察している ${ }^{23,24)}$. 水銀および 金電極に打ける吸着水素原子の生成に関する報告は，これま でに無いことから，水銀アドアトム修飾電極における NDR の生じる原因は，上述した電極表面における $\mathrm{OH}_{\mathrm{ad}}$ の減少に よる電極触媒能の低下に起因すると考えることができる．実 際に-0.5 V 付近における $\mathrm{OH}_{\mathrm{ad}}$ の還元反応（式(3)）が $\mathrm{OH}_{\mathrm{ad}}$ の量の減少の原因となっていると考えることができ,

$$
\begin{aligned}
& \mathrm{H}_{2} \mathrm{O}_{2}+\mathrm{H}^{+}+\mathrm{e}^{-} \longrightarrow \mathrm{OH}_{\mathrm{ad}}+\mathrm{H}_{2} \mathrm{O} \\
& \mathrm{H}_{2} \mathrm{O}_{2}+\mathrm{H}^{+}+\mathrm{OH}_{\mathrm{ad}}+\mathrm{e}^{-} \longrightarrow 2 \mathrm{OH}_{\mathrm{ad}}+\mathrm{H}_{2} \mathrm{O} \\
& \mathrm{OH}_{\mathrm{ad}}+\mathrm{H}^{+}+\mathrm{e}^{-} \longrightarrow \mathrm{H}_{2} \mathrm{O}
\end{aligned}
$$

$\mathrm{Au}$ [100] ${ }^{17)}$ ，銀多結晶電極 ${ }^{13)}$ な゙において，その反応の報 告がなされている。このNDRの生じる原因に基づき振動現 象の生成機構を考察すると以下のようになる。式(1)により 生成した $\mathrm{OH}_{\mathrm{ad}}$ は，式(2) の反応の触媒となり， $\mathrm{H}_{2} \mathrm{O}_{2}$ の還 元反応を加速度的に促進し，還元電流が急激に増加する. し かし，式(2) の反応に执いても $\mathrm{OH}_{\mathrm{ad}}$ が生成するため， $\mathrm{H}_{2} \mathrm{O}_{2}$ の還元反応が進行するに従い，生成した $\mathrm{OH}_{\mathrm{ad}}$ の吸着するサ イトが減少し, $\mathrm{H}_{2} \mathrm{O}_{2}$ の還元反応が進行しなくなり, 還元電 流が減少し始める.この現象は, 反応が進行するに従い, $\mathrm{H}_{2} \mathrm{O}_{2}$ の電極表面濃度が減少することにも助長される.さら に，振動が生じるための必要条件として電流の増減に従い， 電極/溶液界面にかかる電位勾配の違いが生じることが，こ こに加わる，つまり，還元電流が大きい場合には，IRドロ ップが大きくなり，実際に印加している電位より小さな電位 勾配が電極/溶液界面にかかり, NDR 領域より,より正の電
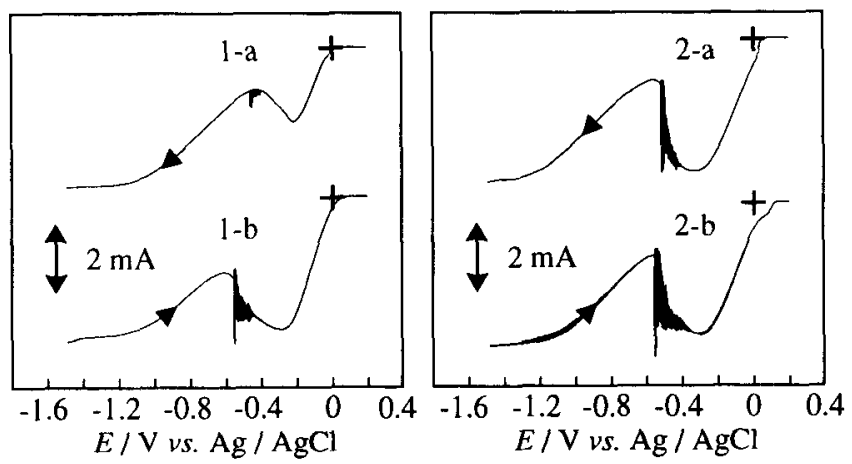

Fig. 3 Steady-state voltammograms for the reduction of $\mathrm{H}_{2} \mathrm{O}_{2}$ on $\mathrm{Hg}$ adatom-modified rotating disk $\mathrm{Au}$ electrode in deaerated solutions of $\mathrm{pH} 7.0$ (1) and 3.0 (2) containing $0.1 \mathrm{M} \mathrm{KCl}$ and $10.0 \mathrm{mM} \mathrm{H}_{2} \mathrm{O}_{2}$. Potential scan rate: $3 \mathrm{mVs}^{-1}$. The electrode potential was scanned in the (a) cathodic and (b) anodic directions.
位で反応が起こり $\mathrm{OH}_{\mathrm{ad}}$ に触媒された還元反応の電流が急激 に増加するが, その後, 電流が隇少し始め, IR ドロップが 小さくなり始めると, $\mathrm{OH}_{\mathrm{ad}}$ の還元反応の領域に界面にかか る電位勾配ぶ戻ることにより $\mathrm{OH}_{\mathrm{ad}}$ が還元される。これによ り $\mathrm{OH}_{\mathrm{ad}}$ は, $\mathrm{OH}^{-}$に還元され，電極表面から脱離し，水銀ア ドアトム金電極表面の $\mathrm{H}_{2} \mathrm{O}_{2}$ 還元触媒能が急激に滅少するこ とにより, $\mathrm{H}_{2} \mathrm{O}_{2}$ の還元反応の電流の滅少が助長される。さ らに時間が進むと電極表面の $\mathrm{H}_{2} \mathrm{O}_{2}$ 濃度が増加することから， また, 式(1)により $\mathrm{OH}_{\mathrm{ad}}$ を生成し, 生成した $\mathrm{OH}_{\mathrm{ad}} に よ り$ 急激に電流値が増加することにより，振動が繰り返し現れる と考えることができる。ここで式 (2) は振動反応に良く見ら れる $\mathrm{OH}_{\mathrm{ad}}$ に関する自己触媒的反応であり，振動現象の出現 に必要な反応の非線形性が生じていることがわかる。また， $\mathrm{OH}_{\mathrm{ad}}$ の吸着サイトの占有による $\mathrm{H}_{2} \mathrm{O}_{2}$ の還元反応の抑制, および式(3)による触媒能の消滅，つまり $\mathrm{OH}_{\mathrm{ad}}$ の生成（式 (1)) ・消滅 (式 (3)) が繰り返しが式 (2) の自己触媒的反応 の進行の度合いをフィードバック制御していることがわかる。 溶液の $\mathrm{pH}, \mathrm{H}_{2} \mathrm{O}_{2}$ の濃度により振動の振幅, およびそれら が観察される電位幅が大きく変化している現象は，界面にか かる電位差の違いにより説明される，振動の振幅の大きさは， 分岐点（振動の始まる電位）加現在振動を観測している電 位の電位差で決まることから, 溶液の $\mathrm{pH}, \mathrm{H}_{2} \mathrm{O}_{2}$ の濃度が 振動が始まる電位を変えることにより，その振幅の大きさを 変化させているためであると考えることができる，また，振 動が観察さ扎る電位幅が変化する理由についても, 分岐点の 位置が変化することにより，分岐点と観測点の差が大きくな ったり，小さくなったりすることにより理解することができ る.

次に，電流振動の電位掃引方向の依存性について検討した。 Fig. 3 は，pH 7.0 および 3.0 の溶液でカソードおよびアノー ド方向への電位掃引で得られる $\mathrm{H}_{2} \mathrm{O}_{2}$ の還元反応に対する対 流ボルタモグラムである、いずれの $\mathrm{pH}$ の場合も，カソード 方向への電位掃引に比べ，アノード方向への電位掃引の場合 の方が，振幅执よび振動が観察される電位幅が大きいことが わかる．また，pH 7.0 の溶液においては， $\mathrm{pH} 3.0$ の溶液に 比べて，電位掃引方向の違いによる振動の振幅，および振動 が観察される電位幅が大きいことがわかる。ささらに， 0.25 $\mathrm{V}$ 付近の $\mathrm{H}_{2} \mathrm{O}_{2}$ の還元反応のピーク電流值について見てみる と, $\mathrm{pH} 7.0$ の溶液に扔いては, 振動の振幅が大きいアノ一 ド方向への電位掃引の場合の方がカソード方向への電位掃引 の場合に比べ，その電流值が大きいことがわかる.一方， $\mathrm{pH} 3.0$ の場合は，電流振動の場合と同様に電位掃引方向の 違いによる還元ピーク電流值の違いはそれほど大きくはない. これらを総合すると，振動の大きさ，および振動が観察され る電位幅と還元ピーク電流值の間には密接な関係が存在する ことがわかる。これらの挙動を上述の電極表面における $\mathrm{OH}_{\mathrm{ad}}$ に関する考えに基づいて考察すると，アノード方向へ の電位掃引の場合， $-0.65 \mathrm{~V}$ 付近までに起こる $\mathrm{H}_{2} \mathrm{O}_{2}$ の還元 反応（式(1) あるいは（2）によって電極表面に生成する $\mathrm{OH}_{\mathrm{ad}}$ が約ー0.5 Vより正の電位における $\mathrm{H}_{2} \mathrm{O}_{2}$ の還元反忍を 促進するための初期反応触媒種となり，結果として大きな還 元電流を生じさせていると考えることができる.この中で電 極近傍の $\mathrm{pH} ， \mathrm{H}_{2} \mathrm{O}_{2}$ の濃度が大きく変化することにより， 振幅㧍よび振動が観察される電位幅が大きく変化していると 考えることができる。一方， $\mathrm{pH} 3.0$ においては， $\mathrm{H}_{2} \mathrm{O}_{2}$ の還 
元反応がどちらの方向からでも非常に速く進行するため，力 ソード方向からの電位掃引とアノードからの電位掃引によっ て電極表面に生成する $\mathrm{OH}_{\mathrm{ad}}$ の量が，ほとんど変わらず，結 果として $\mathrm{H}_{2} \mathrm{O}_{2}$ の還元電流の大きな違いは生じず, 電極近傍 の状態がそれほど違わなくなっていることによると考えるこ とができる。

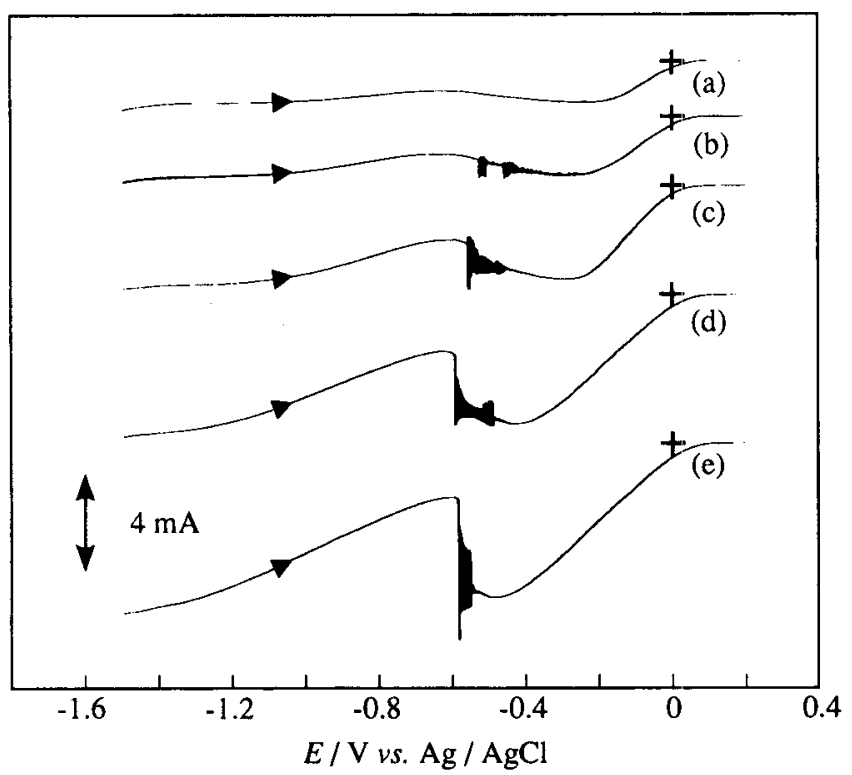

Fig. 4 Steady-state voltammograms for the reduction of $\mathrm{H}_{2} \mathrm{O}_{2}$ on $\mathrm{Hg}$ adatom-modified rotating disk $\mathrm{Au}$ electrode in deaerated solution of $\mathrm{pH} 7$ containing $0.1 \mathrm{M} \mathrm{KCl}$ and $10.0 \mathrm{mM}$ $\mathrm{H}_{2} \mathrm{O}_{2}$. Potential scan rate: $3 \mathrm{mVs}^{-1}$, electrode rotation rate: (a) 100, (b) 200, (c) 400, (d) 900, (e) $1600 \mathrm{rpm}$.

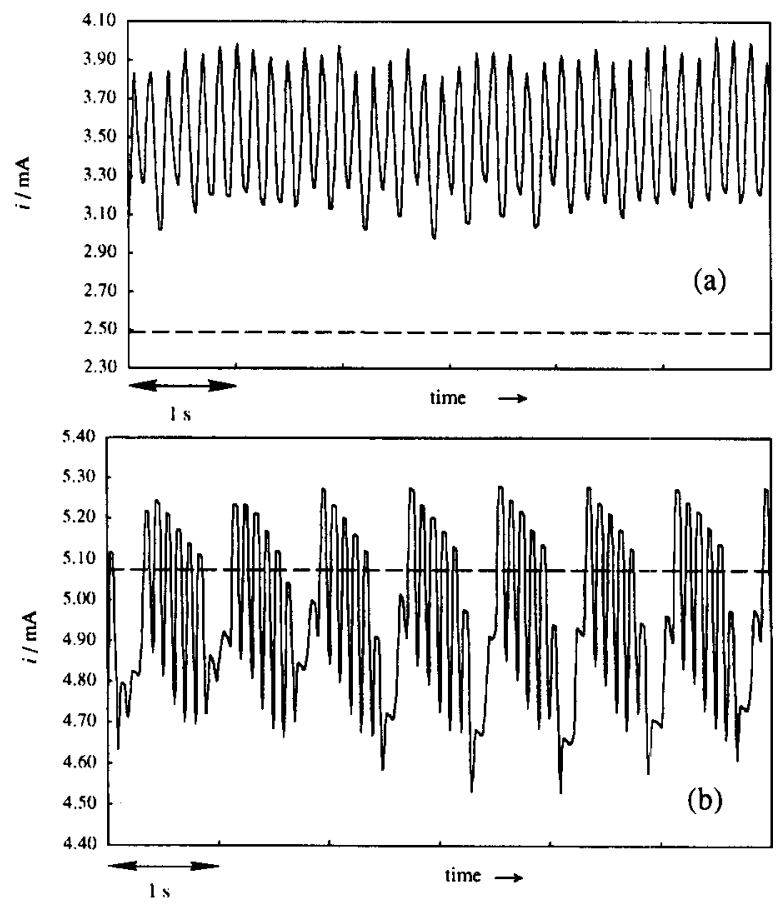

Fig. 5 Current oscillation patterns during the constant potential reduction of $\mathrm{H}_{2} \mathrm{O}_{2}$ at -0.55 (solid lines) and -0.4 (dotted lines) $\mathrm{V}$ on $\mathrm{Hg}$ adatom-modified Au electrode in deaerated solution of $\mathrm{pH} 7.0$ containing $0.1 \mathrm{M} \mathrm{KCl}$ and $10.0 \mathrm{mM} \mathrm{H} \mathrm{O}_{2}$. Electrode rotation rate: (a) 400 and (b) $900 \mathrm{rpm}$.
また, 電流振動と電極回転速度との関係について検討した ところ (Fig. 4), 回転速度が大きくなるに従って, $\mathrm{H}_{2} \mathrm{O}_{2}$ の 還元電流が大きくなり, 振動の振幅, および振動が観察され る電位幅が増加した。この結果は, 上述の結果と良い相関関 保を示している.

次に振動のパターンを検討するために異なる電極回転速度 に扔いて電極電位を一定とし, その時の電流変化を観察した (Fig. 5).400, $900 \mathrm{rpm}$ のどちらの電極回転速度においても 振動が起こる電位に電極電位を設定した場合, その振動は電 極の回転を止めるまで保持された。一方, 振動が観察されな い電位に電極電位を設定した場合には, 規則的な振動は全く 観察されなかった。また, 電極回転速度によってその振動の パターンは，全く違う振動パターンを示した。これらの振動 パターンは, 電極回転速度に非常に敏感であり, 回転速度を 変化させた場合, 10 秒以内にその回転速度に基づく振動パ ターンに移行した。 $400 \mathrm{rpm} に$ において得られた振動は, 比較 的調和振動に近い振動パターンを示しているものの, その振 幅の大きさにあまり規則性は見られなかった。一方，900 $\mathrm{rpm}$ の条件において得られた振動パターンは, 振動数に関 しては $400 \mathrm{rpm}$ に比べほとんど変化しなかったが, 様々な 振幅の大きさを持つ 8 つ振動が 1 つのグループを作り, こ のパターンが繰り返し現れる周期性の高い振動形態を示して いる.このような複数の振動が重なった振動パターンは,

Koperらにより多結晶白金電極における $\mathrm{H}_{2} \mathrm{O}_{2}$ の還元反応に おいて報告されているが12)，その発生の原因などの詳細につ いては，まだ十分に議論されて扔らず，我々も上述した単純 な反応機構だけではこれらの振動パターンを再現するには至 っていない，現在，さらなる反応経路を考案することにより 振動パターンを再現する計算を行っている.

\section{4 結 論}

水銀アドアトム修飾金電極において $\mathrm{H}_{2} \mathrm{O}_{2}$ の還元反応が促 進されること, そしてその還元過程において電流振動が起こ ることをはじめて見出した，振動電流の振幅，および振動が 観察される電位幅は, $\mathrm{H}_{2} \mathrm{O}_{2}$ の濃度, $\mathrm{pH}$, 電極回転速度, 電 位掃引方向などに大きく依存することがわかった．金 [100] 単結晶電極 ${ }^{17}$ おおよび銀多結晶電極 ${ }^{13)}$ での $\mathrm{H}_{2} \mathrm{O}_{2}$ の還元 反応における同様の振動現象との比較に基づいて，水銀アド アトム電極表面に吸着した $\mathrm{OH}$ 種 $\left(\mathrm{OH}_{\mathrm{ad}}\right)$ によって $\mathrm{H}_{2} \mathrm{O}_{2}$ の還元反応が促進され，そして $\mathrm{H}_{2} \mathrm{O}_{2}$ の還元反応の電流振動 は $\mathrm{OH}_{\mathrm{ad}}$ の生成・消滅が電極/溶液界面にかかる電位勾配の 変化により繰り返し起こることにより生じると解釈された。 現在，FT-IR，STM などを用いて， $\mathrm{OH}_{\mathrm{ad}}$ の吸着の吸着状態， およびアドアトム原子の配列状態（電極電位依存性）などを 詳しく検討中である25).

\section{謝 辞}

この研究は, 文部科学省科研費 (No.12875164) 及び科研 費（A）（No.10305064）の研究助成金によった。ここに記し て感謝いたします。

\section{文 献}

1) E. B. Yeager, J. Electrochem. Soc., 128, 160C (1981).

2) K. Kinoshita, Electrochemical Oxygen Technology, Wiley, New York, 1992. 
3) Fuel cell handbook, 4th ed., US Department of Energy, 1998.

4) S. Trassati, W. E. O' Grady, in: H. Gerischer, C. W. Tobias (Eds.), Advances in Electrochemistry and Electrochemical Engineering, Vol. 12, Wiley, New York, 1981, p. 177.

5) J. Xu, W. Huang, and R. L. McCreery, J. Electroanal. Chem., 410, 235 (1996).

6) Y. O. Su, T. Kuwana, and S. M. Chen, J. Electroanal. Chem., 288, 177 (1990).

7) J. Wang, N. Naser, L. Angnes, H. Wu, and L. Chen, Anal. Chem., 64, 1285 (1992).

8) T. Nagaoka, T. Sakai, K. Ogura, and T. Yoshino, Anal. Chem., 58, 1953 (1986).

9) J. Prakash and H. Joachin, Electrochim. Acta, 45, 2289 (2000).

10) J. Perez, H. M. Villullas, and E. R. Gonzalez, J. Electroanal. Chem., 435, 179 (1997).

11) M. T. M. Koper, A. M. Chaparro, H. Tributsch, and D. Vanmaekelbergh, Langmuir, 14, 3926 (1998).

12) T. G. J. van Venrooij and M. T. M. Koper, Electrochim. Acta, 40, 1689 (1995).

13) G. Flatgen, S. Wasle, M. Lubke, C. Eickes, G. Radhakrishnan, K. Doblhofer, and G. Ertl, Electrochim. Acta, 44, 4499 (1999).
14) H. Tributsch, Berichte der Bunsen-Gesellschaft, 79, 570 (1975).

15) T. Matsuda, H. Hommura, Y. Mukouyama, S. Yae, and Y. Nakato, J. Electrochem. Soc., 144, 1988 (1997).

16) E. R. Savinova, S. Wasle, and K. Doblhofer, Electrochim. Acta, 44, 1341 (1998).

17) S. Strbac and R. R. Adżic, J. Electroanal. Chem., 337, 355 (1992).

18) K. Krischer, Modern Aspects of Eectrochemistry, Vol. 32 , B. E. Conway, J. O'M. Bockris, R. E. White, Plenum, New York (1999), p.1.

19) P. Strasser, M. Eiswirth, and M. T. M. Koper, J. Electroanal. Chem., 478, 50 (1999).

20) J. Inukai, S. Sugita, and K. Itaya, J. Electroanal. Chem., 403, 159 (1996).

21) U. Oesch and J. Janata, Electrochim. Acta, 28, 1237 (1983).

22) C. Paliteiro, A. Hamnett, and J. B. Goodenough, J. Electroanal. Chem., 234, 193 (1987).

23) Y. Mukouyama, S. Nakanishi, H. Konishi, and Y. Nakato, J. Electroanal. Chem., 473, 156 (1999).

24) S. Nakanishi, Y. Mukouyama, K. Karasumi, A. Imanishi, N. Furuya, and Y. Nakato, J. Phys. Chem. B, 104, 4188 (2000).

25) F. Matsumoto, S. Uesugi, N. Koura, and T. Ohsaka, in preparation. 